Original scientific paper

Submitted: 2020-03-01

doi:10.5937/nabepo25-25498

Published: 2020-06-02

\title{
CONFLICTS AND DEMOCRACY IN ETHNICALLY COMPLEX SOCIETIES AND ROLE OF MEDIA THE CASE OF YUGOSLAVIA IN 1999 Intervention, victims and stereotypes
}

\author{
Slobodan M. Penezić ${ }^{1}$ \\ Serbian Official Gazette, Belgrade, Serbia \\ Milija Ž. Cvijović \\ Serbian Chamber of Commerce, Belgrade, Serbia
}

\begin{abstract}
The text herein is inspired by Hans Magnus Enzensberger and his writings about "nucleated" civil wars initiated by interethnic differences. Placing his thoughts in context of media, he sees those wars as a spectacle which makes the audience perceive it as a moral problem. The paradigm for interpreting these conclusions may also be the influence of media on perception of events in Yugoslavia in 1999. The starting questions are, therefore, directed towards analysing the validity of such conclusions, which we try to do by explaining the nature of relationship between wars and media influence, as well as the origin of stereotypes about the Balkans - their multiplication with start of conflict and influence of the media on it. In doing so, we can also notice the misconceptions and the effects they produced; with parallel analysis of the essential principles of journalistic reporting, but also a clear disregard for them, with the aim to show their causes too. This makes it possible to deduce what was the effect of reporting and how much it led to problem-solving and transformation of the Balkan societies, or it caused new stereotyping and problems. In this way, all the pointlessness of the conflict and NATO's interventions are also demonstrated, and the conclusion of the analysis becomes a confirmation of Enzensberger's thinking.
\end{abstract}

Keywords: Yugoslavia, NATO bombing, media reporting, journalism ethics, the Balkans, interethnic conflicts.

$\overline{1 \text { Corresponding }}$ author: penezicslobodan@gmail.com 


\section{INTRODUCTION}

Enzensberger's conclusions on conflicts, such as those that happened in former Yugoslavia at the end of the $20^{\text {th }}$ century, point out that ideology is reduced to the most brutal forms of violence, without thinking about the consequences, which leads to self-destruction. Therefore, he suggests that the reality is different, and that such problems should be solved before they become part of the global political agenda (Enzensberger, 1994: 29). The impression is that we have to state its validity, when it is obvious that the majority of international interventions represent a kind of hypocrisy, manifested through violent intervention and accompanied by unjustified preaching of big and powerful, which Enzensberger also notes in this place. He points out that this approach is constant of foreign politics of great powers, while, unfortunately, one of the constants of politics in this area represents a departure from reality, which leads to frequent interpersonal conflicts. The paradox of the politics of the Balkan states, therefore, is also reflected in the insistence on non-interference of the others, while, at the same time, expecting that our problems could only be resolved by intervention from the outside. Enzensberger argues that today the media inform the public in a way that the war can become a moral problem, and that influential nations and individuals act only when the fight for protection of moral coincide with their own interests. Therefore, such focus is suitable for the study from the perspective of deeply-divided societies in the Balkans (Enzensberger also did), and an adequate paradigm for the analysis is an influence of the media on the perception of events in former Yugoslavia. He also refers to it by saying that the interests of the big for conflicts of the small runs only while it is a good content of a new media spectacle. This text is framed by the events during the NATO intervention in Yugoslavia 1999, but also after that, because it is difficult and scientifically incorrect to analyse this period isolated. Analyses of narrative and discourse within which the content of the media was created show their impact, and also pose the question at the same time - how much they follow the norms of journalistic professionalism and desire to help solving of the problem, or it has led to the new stereotypes and more complex problems, by violating the basic principles of the profession? In that way, we recognize the effects of media messages on the society and the individuals, who often know little about the far distant regions, as well as their causes: but also the consequences of constant stereotyping (stigmatization) of the Balkans.

\section{VERSIONS AND CONSEQUENCES}

General guidelines of the European Convention on Human Rights, considering the fact that most of them get ignored in the war, are a good introduction for further consideration of this article thesis. This was also the case in
Yugoslavia in 1999, because it is obvious that they have been violated by all parties, but also by those who, paradoxically, started their activities with referring to them, given the fact that the NATO intervention was contrary to the 
second article of the UN Charter, the fifth article of the NATO Agreement, and the constitutions of most countries in the NATO coalition. The wars in the Balkans were also an opportunity for intellectuals to express themselves. The bombing, for example, was supported by Mario Vargas Llosa, Michael Walzer and Bernard-Henri Lévy, while others, such as Regis Debray, Peter Handke and Noam Chomsky were against it, and they experienced the intellectual-media lynching because of it. Debreu tried to point out his position, by explaining: "I am not pro-Serbian, nor anti-Serbian; as it tries to impose, but I am against all types of Empire" (Debreu, quoted according to Kokanus, 1999). Volzer, a supporter of the so-called "Just war theory", 2 at the presentation of his book in Belgrade, however, explained that the war in Bosnia was experienced through images presented by the Western media, and that he "supported the intervention, under the influence of these", and admitted also that "his and many intellectuals' attitudes regarding the NATO bombing in 1999 were inspired by the media coverage of Bosnia", but he also said that he "stressed that such act will not resolve the problems" (Predstavljanje knjiga Majkla Volzera, 2010). The version, supported by most of the Western media and the public, referenced this epilogue: international organizations and most of the Western media reported that the massacre in Račak happened on January 15, 1999, where the Serbian troops, allegedly, killed 45 Albanians. This event, the subject of many controversy, was a turning point because despite all legal and humanitarian arguments, a decision was taken for the NATO to inter- vene militarily, justified by the desire to prevent further conflict: the NATO had threatened that it would begin its intervention if the Serbian army did not withdraw from Kosovo and let the peacekeepers deploy there, which was not accepted by the Serbian leaders, and it led to the bombing of Yugoslavia, from March 22 till June 11, after which Kosovo came under the UN administration.

To analyse the situation in the Balkans, and not to refer at least briefly to the dimension of the impact of political decisions, would be, at least, incomplete. Anti-Serb hysteria that spread from official sources to the media, who openly put themselves into their service, was created "slowly and imperceptibly, creating the basis for the military involvement of the Western allies, but the leader of the last big country in the Balkans also did not recognize that circumstances have changed", observes Jevtović, and noting that he (Milosević) and his associates "might missed the directive NSDD No.54 (US Policy Towards Easter Europe) of the Council for national security (1982) and Directive No. NSDD. 133 (US Policy towards Yugoslavia), which as early as in 1984 determined the general plan for breaking up of Yugoslavia, and rapid reintegration of the new regime in the global corporate environment" (Jevtović, 2017: 65). Michael "Misha" Glenny, who often criticized Serbs, explored the often bad relationship between the Balkans and the Great Powers, and stated that the Western intervention is one of the main causes of such a problem and that "intervention in Kosovo is the same", with accentuating the wrong efforts to solve the problem by making a new bloodshed (Glenny, 2012: 635). Ac-

2 This theory is based on the view that military interventions, which are of a so-called humanitarian nature, are justified, because they aim to defend those who are subjected to tyranny, and thus such wars are similar to those that are waged for self-defence. 
cording to the Serbian sources, since the NATO attacks started "114 policemen and 462 soldiers died, and the death of civilians is still questionable, but estimates range from 1,200 to 5,700 ", while the NATO announced that it could cause a murder of 1,500 civilians, with no casualties outside Kosovo: with that number (at least 1,200 civilians) it goes to a number of around 15,300 dead (Human Rights Watch, 2009). However we try to aggregate such data, the result is tragic, and the question of a true cause inevitably pop-ups; hence the justification of the NATO intervention, but also the role of the media. That is why Jevtović and Bajić are taking the perspective of "media centrism" in their analysis as "important doctrine hybrid war, based on a combination of ideological, propaganda, intelligence and psychological operation in which the imposition of symbolic concepts and targeting sense to focus public opinion" (Jevtović \& Bajić 2019: 111). Even a brief analysis of media coverage proves such a choice as a correct one, indicating the consequences at the same time. NATO began to influence the media from the start of its intervention, but journalists also voluntarily published the news that contributed to that side. Therefore, it is clear that the war propaganda nowadays "is not old-fashioned censorship, but knowledge to capture images that cannot be resisted", writes Klun, also noting that "the lack of discussion about the issue is a result of image uniformity, and that is how it became easier to assure the public, while the simulated polls assured politicians" (Klun, 2000: 78). The media as a "means of pressure are nothing new, because, by manipulating people with their fears, they are acting on their homogenization", correctly observes Jevtović, who concludes that in the complex circumstances in Yugoslavia, the story of "Yugoslavia was too complicated", while "anti-Serb narratives were simple and clear" (Jevtović, 2017: 66).

\section{CONFLICT AND MEDIA, JOURNALISM ETHICS AND VICTIMS}

War conflict is one of the constants of humanity and it is impossible to express all its horrors by the numbers. According to some data, only in the last decade the result shows that more than two million children have died and more than one million were orphaned. In the important documents of the US military, RAND: Project-AIR FORCE, it is stated that the West has a mission to prevent the killing of civilians in the war, but also that the media and the public believe that civilian casualties are used as a justification for their participation, and hence the concern for public support (Larson \& Savych, 2006). Numerous explanations, such as those of "ancient hatreds"3 or "security dilemma" still do not give a complete picture of the situation and the causes of such conflicts. The problem is also the lack of knowledge of media impact on the conflict. Jusić, therefore,

3 The theory-explanation rooted in ethnological, even anthropological assumptions, from which, allegedly, originates the predisposition of certain peoples-nations-communities to start a conflict when circumstances prompt it.

4 The term-explanation-theory in international relations, which is applied when a country, when seeking to increase its security (e.g. by strengthening military strength or forming alliances), also influences others in the environment to respond with similar measures, which inevitably leads to tension, and often causes a conflict. 
concludes that "the media influence the conflict, while conflict and its context have an impact on the media at the same time, because of which media involvement in monitoring conflicts is shaping public reaction" (Jusić, 2008: 40-63). It is obvious that the political influence of the actors of the conflict affects the attitudes of the public, and therefore the image that the media present, which, in turn, focus on the topics which are primarily interesting to the domestic public. Barović recalls that war stories are always the first news; and a good example of that happened during the bombing of Yugoslavia: "CNN daily budget was \$ 150,000 and it had losses of over 1.5 million dollars". That is why he also notes that "the media did not invent war, but that we must admit as justified that they figuratively introduced it to the homes of consumers of information" (Barović, 2008: 143-152). At the same time, he also says that the largest number of reporters followed the events in Kosovo without preparation and knowledge, and, therefore, stressed that "for the cause of the quality of reporting and personal safety, a journalist has an obligation to become familiar with a number of elements" (Barović, 2008: 143-152). Branko Klun notes that the situation intensified after a report on Račak, because such images "contribute to shaping public opinion which allows politicians to justify their strategies" (Klun, 2000: 78). The case, which is often taken as an example of bad reporting is the CNN report in April 1999, and the image of Albanian refugees and the girl crying, while snowing outside, when winter is long gone, a temperature is at around 18 degrees (Salmon, 2010: 98). Jevtović, therefore, justifiably refers to the so-called doctrine of low intensity conflict, which is being analysed in this example of Račak, which means a model of the intervention in three phases: 1) media preparation of the public; 2) causing the intervention, and 3) a media offensive (Jevtović, 2017: 72). In an article which is also signed by Bajić, Jevtović refers to two other techniques applied in Yugoslavia 1999, at the centre of which is also the media: doctrine of low intensity conflict and the technique of provoking informative silence. According to the former, "media in crisis situations have the task of inflaming emotions, so that facts are marginalized". The latter was first applied in this case: "The number of transmitters and their audibility in neighbouring countries has tripled, muffling the signals from the Serbia and in the airspace the electronic communication made the hoop to prevent penetration of unwanted opinions" (Jevtović \& Bajić 2019: 120). The power of the media is what makes journalists responsible for the veracity of their contents. Problems arise when you need to determine what and, especially, how to report. Freedom of the media is, however, the assumption of a free society, and vice versa, and journalistic ethics "must refer to the public, to whom it is intended in the first place" (Žaket, 2007: 12). Žaket also writes that, if we ask ourselves about the cause of the existence of journalists, the answer is to provide essential services: "to collect data and report on the news, so that we can use them, however, as in the case of every valuable and potentially hazardous substance, its purity is of the utmost importance" (Žaket, 2007: 17). Media theorists, thus, believe that the media have a special status in society only thanks to the objectivity of the journalists, which is, according to Allan: "journalistic standards and a resource for protection of pressure" (Allan, 1997: 297). Analysis of the norms of journalistic ethics may be hardly achievable, but which we must 
strive for, therefore, provides us with an answer to a following question - what kind of help it is for the journalists and the public which they should serve? It is clear that the media in the case of Yugoslavia in 1999 solidly betrayed its ideals, failing to answer the questions that are now imperative of good reporting: causes (Why?), which requires that the media should place an event into a broader context; and consequences (What next?), which suggests that we need to point out its further development. Peter A. Brock analysed why the journalists agreed to trample the principles of their profession. He uses the term "media cleaning", tailored to the source of news stories about "ethnic cleansing", that have "led to a decade of war and persistent problems in the Balkans for all", where journalists "deliberately put themselves as the service of propaganda of war and contributed to the Balkans perception as a region of evil, that will deeply destabilize Europe" (Brock, 2006: 8). He reminded about the example of David Binder, the The New York Times journalist, with rich experience of reporting from the Balkans. When he tried to point out to the deeper causes of problems in this region, which also depicted Albanians as negative, the editors did not accept the texts, and they were not published, so he had to write about it in other newspapers. Through the phrases that journalists use, we can also identify the attitudes of politicians on developments in this region, and Mirjana Vasović estimated that the euphemisms (such as, collateral damage, ethnic cleansing...) were sought to prevent the setting up of ethical issues (Vasović, 2004). Critics often estimate that the media lack integrity and professionalism, because they accept censorship and repackaging of the facts in order to support the government and offi- cial sources. That is how the once-called "watchdog of democracy" has become a means of propaganda, promoter of dubious interests and an "obedient poodle" (Reljić, 2011: 56).

It is clear that ethics was not the most important in reporting from the Balkans. The reasons are also in working conditions for journalists, but we can notice a large number of those who have deliberately misled the public for the sake of a support for a particular politics and interests. Todorova points out that "foreign news are always easier to distort" (NIN (2006, 7th of January)), while Stojanović says that, unlike domestic news story, in international ability to control rapidly decreases, primarily due to the physical distance (Stojanović, 2000). Therefore, after all, how Papagiannis concludes: "All stories should be explored in a broader context" (Šajkaš, 2007). Otherwise, the results are inaccurate generalizations and conclusions. That is why Diana Johnstone concludes "that the analogies must be drawn cautiously, as they should not cloud the fact" (Johnstone, 2002: 25). In the way of reporting from the Balkans, Vesna Goldsworthy also sees "an opportunity to achieve imperialism of the Westerners, about drawing borders and step towards organizing the rebellious natives" (Goldsvorti, 2000: 3). In trying to explain the war in the Balkans as predestined by the Balkan people to kill each other diminished the ability to prevent it. This mechanism can still be seen in the perception of these people, so the stereotypes about Serbs are also based on it. In practice, they are described as "filters". Herman and Chomsky created a model of their analysis, that examines the impact of economic and political elites on the media, but they also note that major US dailies, during the 1990s did not 
publish any articles written by the people of Serbian origin, so it is logical that the Serbs, on the basis of general prejudice of the Balkans, became synonymous of evil (Brock, 2006). Modern trends that are transforming the world into a global village, with the dictation of the global economy trends, dominant ideologies and political power influenced from the few centres, put before the media the task to explain the local events in a way that is understandable globally.

\section{INTERVENTION, PROPAGANDA AND STEREOTYPES}

When you look at the titles of some media, it is appropriate to question the consequences. Many of them justifiably criticized certain features of political leaders and their loyal media, but the approach of most of them encouraged even greater chaos. A few days before the bombing, Jason Fields from Associated Press wrote that: "The Balkans is destroyed by the hatred among its ethnic groups, all of which have something in common Balkan Peninsula, and to find something else would be a real challenge" (NIN (2006, 7th of January)). This statement sufficiently indicates the attitude of most of the Western media and the public.

David Model believes that it is easy to notice that the Western media had not a critical approach to NATO, and presents an article written by Chris Hedges on June 2, 1998, for The New York Times, where he wrote that "Milosević, despite the efforts of American diplomacy to come to negotiations, is determined to destroy the resistance of Kosovo Albanians", but he forgot to say (Model noticed) that the KLA had attacked Serbs, and that the Serbian police arrived in Kosovo to prevent it (Model, 2005: 5). Model also alleges that $\mathrm{CNN}$ quoted Madeleine Albright, then the U. S. Secretary of State, on March 24, 1999, who said that the goal of NATO is not to harm innocent people, whose "truth" revealed later. Thus he concludes that "the writing of some American media is a real example of official control of state administration, because the stories are drawn from administrative sources, without checking the information from the field" (Model, 2005: 5). Kačanik case is particularly interesting, because it became a place of an international circus in just one day, where all media people raced trying to be the first to discover, allegedly, mass graves of innocent civilians. The newspaper Independent reported on June 15, 1999, that the bodies were buried under several inches of the ground, because the Serbs ran out of time. The text is, however, in contradiction with that headline, because in that case they would not have time to bury the bodies and dig graves for new victims, as also described within the article.

Overview of several earlier articles in this newspaper points to a different focus of content in the previous period, which supports the thesis that the media skilfully steered around official politics. For example, David Binder on January 1, 1987, wrote that "ethnic differences and tensions clearly point to the possibility of civil war, and that the paramilitary forces of Albanians, who are wellarmed and have separatist ambitions, are increasingly attacking Serbs, wishing to provoke their reaction". He was later withdrawn from the Balkans, and that is why many experts, like Phil Hammond, 
stand out that even when the journalists tried to reported correctly, the editors hesitated to published it, if it was different from the official policy (Hammond, 2000). That is why analyses should not lead to the generalization, which would disqualify the entire media, because we can also notice some cases of professional reporting. Some of them wrote about the errors of NATO, as well as about the crimes committed by Albanians. Paul Watson from The Los Angeles Times is one of them, who had been in Kosovo during the conflict, and his articles consistently represented the complexity of the situation. A well-known case, which Hammond describes, is the text about an Albanian Saipu Reci, the pro-Yugoslav soldier of the Yugoslav Army, which the editorial board did not want to publish, because it did not fit into the image that officials insisted on (Hammond, 2000). Such examples are also the texts written by Jeffrey Smith from The Washington Post, who wrote in July 1999 about the bombing that killed two Kosovo Serbs, and about the fact that more than 330 Serbian civilians were killed since the NATO forces entered in Kosovo. He also noted that violence against Serbs is surprisingly brutal, and revealed how it happened that the KLA remained under arms, because Albright convinced Gerhard Schröder to agree on the conversion of the KLA into a civilian national guard, which was also opposed by Britain. The New York Times also published an article on the KLA, stated that in the absence of a stronger international presence, it established wide control. The Western media mostly described Milosević as the organizer of the war, in order to build a "Greater Serbia", through "ethnic cleansing". The called him "a butcher of Belgrade" and a "criminal leader", and compared him to Hitler, while Serbian soldiers were portrayed by the model of film villains. Michael Parenti, however, noted that they did not immediately adopt such a view of Milosević - it happened later, when he was seen as a goal, not as an instrument (Parenti, 2003). Michael Mandel, therefore, analyses Balkan wars through its participants, their motivation and strategy, and most importantly - through the role of external actors (PR company, Western European powers, UN ...) - his focus is on the role of the media, which, according to him, share responsibility in encouraging conflict, and the role of the journalist-government agitators for the politics of the conflict in the former Yugoslavia. Media initiatives for more concrete military action "under the excuse of prevention of ethnic cleansing, was used to justify the war propaganda; and magnified problems and prejudices about the Balkan peoples", he concludes (Mandell, 2004: 98). Diana Johnstone points out that "the focus on the concept of 'justice' and attempts to present that the Serbs are the only ones responsible for crimes, was actually the backbone of the Bosnian Muslims and then Kosovar Albanians" (Johnstone, 2000: 5). Mandel and Johnston, therefore, equally recognized that journalists were easily convinced that the fight against evil, which was represented by the Serbs, meant liabilities and less risk; and began to simplify the situation and sympathize with administrative sources, eventually becoming addicted to them (mainly the UN and NATO). In the analysis of The New York Times reporting by Edward Herman, he uses a sample of 120 articles written by Marlies Simons, and concludes that she even established "a clear pattern of writing in order to favorize NATO interpretation", which also supports the arguments of those who criticize the lack of interest of 
journalist for the history of the Balkans (Herman, 2005: 6).

Stella Jatras estimates that one of the major examples of bias is The Washington Times, who has become "a part of the liberal propaganda machine, which has led to numerous victims", and she recalls that Philip Smucker wrote about the mass grave in Orahovac at its front page on August 6, 1998, with a picture of a bulldozer on a garbage dump, describing that the bodies of more than 500 Albanians were left there, half of them women and children, and that the Serbs denied the massacre, although the digging did not even start. The very next day, in the same newspaper, but in the corner of the page 15 , there was the news in just two sentences, with no picture, but with the official statement from the NATO that no bodies were found; but with no denial of a previous one - therefore, she concludes that "the borders in the formulation of the story has nothing to do with accuracy, but with what brings rewards" (Jatras, 2001). Edward Herman recalls the statement by General Lewis Mackenzie, former commander of UNPROFOR, in the newspaper The Globe \& Mail, on June 15, 2005, where he said that "the picture is much more complex than black and white in Western media", and he also notes that the US Department of State said that about 500,000 Albanians were killed, but later it was confirmed that there were up to 7,000 on all sides, but nobody answered or at least acknowledged the mistake. Ted Grant and Alan Woods wrote that the bombing was intended to help the Albanians, but that it made the situation worse for everyone, as also acknowledged by some representatives of NATO, and that is why "NATO raised the propaganda war to a new level", which made it clear that "the first casualty of war is usually the truth" (Grant \& Woods, 2006). NATO propaganda was based on exaggeration and it served as a cover for its intervention. A large media space was also given to the politicians, and it also served for their internal wars, but it affected the public image of the region, too. Thus, the media also, indirectly suggested moves opposite to the principles of law and democracy, which, according to them, was threatened in this region.

From today's perspective, it can be noted that the interest of the Western, and especially American media for the Balkans, was limited to the periods when the domestic public and political structures were, as some authors estimate, hungry for "images of destruction and killing". This is confirmed by the fact that the web-site of, at that time, in Serbia prohibited Radio B92, had as many as 15 million visitors outside the borders of Serbia, in the period of only 10 days. After the culmination of the conflict, when they should specifically indicate the errors and potential responses, the Balkan issues are pushed to the margins of those media. When it comes to the US media, the largest ones, such as The Washington Post and The New York Times, are the only ones who continuously covered events here. Goldsworthy writes that the interest in the West Balkans lasts as long as the wars (Goldsworthy, According to Vesković, 2008), while Aleksa Djilas explains that the American public interest dictates the influence of the media; stating that there is no rooted hatred of the Serbs there, but also that the negative image still exists today, so even when the Serbs are the victims, they try to justify it by blaming it on the bad policy of Milosević and its regime - he also notes one paradox, by saying that it was difficult "to find military officers who openly supported aggressive policy towards 
Serbia, but not journalists", although this is, how he explains, not a surprise "if we have in mind the desire of the media for sensationalism and their irresponsible, because unlike the officers, journalists are unaccountable in that way" (Politika (2003, 23th of June)).

On the other hand, the challenges of globalization, technological revolution and the global economic crisis - the impact of all this on the media, influenced the reduction of media capacities and changes to the way of their functioning. The media management explain such reduction with lower domestic interest for the news from abroad. This is, however, the reason for criticism of the media, which rightly warn that they rely heavily on agency reports and begin to be interested for news abroad only when problems reach a climax, which is resulting in chaotic reporting.

\section{MEDIA AND PROPAGANDA: CAUSES AND CONSEQUENCES}

The importance of the media propaganda, as a component of the war, was familiar to all parties - NATO, but also the regime in Serbia. Most of the media in Serbia followed the myth that the regime created - that Serbia is the winner of "unprovoked aggression", while, for example, The New York Times claimed that NATO bombs caused less damage than it was the case.

Klun illustrates the role of propaganda in the war, by providing an example of the confidential report of Media operations centre, which was conveyed by Der Spiegel, where a spokeswoman for the French Government reported on the growing dilemma in the French public about the attack, and asked to "help with media content, with instructions that the nature should be focused on stories about refugees and Serbian crimes" (Klun, 2000: 78). New technologies have certainly affected the media, and the media construction of reality (wars too), and media technology fundamentally transformed warfare on the other side. Long ago, has noted inconsistency of strategy and rationality of communication (Habermas, 1991), and the criticism of the reporting on Kosovo is related to the strategic influence of official administration in many media. Namely, once dominated the time between the event and its reporting, enabling the creation of news, now does not exist, because strategic rationality dominates and it does not allow a critical deflection and understanding of information, how Paul Virilio states correctly, and warning that "we cannot believe our eyes anymore, because events are manipulated by various directors" (Virilio, 2003). A part of the problem is also that the media "as the fourth pillar of democracy yield in the immediate notification", as noted by the Klun, warning that it is "a threat to an intellect, but also for a man in his being" (Klun, 2000). That is the reason why many intellectuals say that the media today are a threat to rational thinking and democracy.

In addition to these components, in the course of it and after the Yugoslav wars at the end of the $21^{\text {st }}$ century, a plenty of literature on the subject of identity and mentality of the people in the Balkans also appeared. The book that has had a major impact was Balkan Ghosts by Robert D. Kaplan, best-selling about the Balkans in the United States for a long time, 
and the first about this region which, by its own admission, Bill Clinton has read. Kaplan, in turn, wrote about the Balkans as a haunted place and demanded a strong military intervention against the Bosnian Serbs (Kaplan, 1993: 47). That is why Timothy Garton Ash accused him that he gave credibility to allegations that the bloody ethnic conflicts are endemic in the Balkans and that a new war is inevitable. Partial change was made in the book Bosnia: A Short History by Noel Malcolm in 1994, and Richard Holbrooke later emphasized that the Bosnian war would have lasted shorter, if it had been released earlier. He, however, understood it in a way that he concluded from it that the "Balkan history is a mix of complicated and trivial things, which is the best to be ignored" (NIN (2006, January). Milica Bakić-Hayden reasonably concludes that the terms "Balkans" and "balkanization" become suitable for the construction of the symbolic form of the distinction from the "second" and "less civilized" rest of the world, which is also easy to notice in certain media, and that was also the position of the West in relation to Yugoslavia (Bakić-Hayden 2006: 34). Ksenija Šabec notes that expression "balkanization" mainly appears "to describe fragmentation and conflict" (Šabec, 2004), and increased the prejudices about Balkan, as a place where less civilized people live, and the use of "balkanization" as a process that leads to the primitive behaviour. Tim Judah, therefore, emphasizes "the importance of understanding of historical dimension of the events in the Balkans at the late $20^{\text {th }}$ century" (Judah, 2009: 22).

A variety of literature, however, did not result in clear conclusions, mostly because they are directed towards unilateral conclusions and insufficiently reliable sources. It is, therefore, not surprising that most people outside the Balkans, after the breakup of Yugoslavia, place the Balkan from Siberia to Syria and compare it with a lower category of civilization. The complexity of the causes and circumstances of the modern Balkan conflicts have not helped the researcher's work. Hence, perhaps, the attempt of the media for the reactivation and upgrading of old stereotypes was easier for them in order to present the Balkan complexity. Predrag J. Marković writes that "stereotypes are defined as simplified, often prejudiced conception of reality, resistant to change" (Marković, 2001: 205). Stereotypes, as a mixture of fantasy and reality, do not have to be one-dimensional and unchangeable phenomena, because they can be modified; and be negative, neutral or positive. During the crisis, negative ones are multiplying. They often serve a purpose of the projection of personal characteristics on another. As a logical one, there is therefore the question of the source of stereotypes. Simple examination can determine that long before the breakup of Yugoslavia the Balkan peoples were described as primitive. The term "Balkan" quickly became infamous, as soon as it was accepted as the name of this peninsula in mid$19^{\text {th }}$ century, and also its "presentation in a negative light and attempt to make a distance from the negative otherness, which led to new problems and to the impossibility of discovering their causes" (Norris, 2002: 56). That is why it also started "increasingly to imitate that negative image in reality too" (NIN (2006, $16^{\text {th }}$ of January)). Todorova, therefore, concludes that one thing is haunting the culture of the West - bogey of Balkan (Todorova, 2006: 25). Stereotypes of the Balkans, therefore, can be seen through the relationship between media initiatives and policy decisions, and vice ver- 
sa, and it is one of the important topics in the analysis of the events of the late $20^{\text {th }}$ century. Foreign media have had a positive role, alarming about certain things, but a good part of the public and experts consider that they often lack the balance of the information. One of the issues, therefore, is the role of journalists in the war propaganda and their influence in a specific cultural and political context. It is certain that they can contribute to the search for truth, but that they also could be one of the obstacles along the way, as it mostly was in Yugoslavia case, which certainly needs to be deeply investigated.

\section{CONCLUSIONS}

Establishing an adequate conclusion about the impact of media on the events in Yugoslavia in 1999 is still not easy. Perhaps it is not quite possible, because too much was, and still is, in the game - from the obvious economic interest to deep-rooted national sentiment. Therefore, as we see, we can only talk about individual examples and the global position of media in the context of various external influences and their effects on the public, with caution to avoid the pitfalls of constructing conspiracy theories. Discussions about the victims and pictures in the Western media are now reviving occasionally, but they are still clearly biased, and the focus is on the future of the so-called independent Kosovo. On the other side, much louder are the conclusions that NATO intervention did not bring anything good, and, as Jevtović and Bajić also concluded, that "the illusion of NATO effectiveness in resolving the crisis is crushed, despite the power and the media demonization of one side" (Jevtović \& Bajić 2019: 124). Serbian propaganda has also had a share in creating chaos and this is a topic that requires a separate analysis. One of the aspects that should therefore be analysed is that the stereotypes about the Balkans are also encouraged from the inside. Richard Rorty points out that the national pride of the condition of self-improvement of the state does not mean that we should ignore errors that the state is making, and he criticizes politicians who build distance from their people, thinking that they will keep the power in that way, when, in fact, they are doing the opposite (Rorty, 1999: 16), and Jusić correctly assessed that the crucial variable that affects the media during the crisis is the political control (Jusić, 2008).

The paradigm of media impact in this case, therefore, clearly coincides with the estimates of Enzensberger, who also indicates errors of a less powerful nation, while explaining the involvement and impact of the great powers and their media on their future. Yet, another aspect of these conflicts also should be one of the angles of reflection of the context considered here, as an example of a similar manufacture and a discourse which Enzensberger interprets. Maria Todorova writes that since the breakup of Yugoslavia more students around the world are writing the papers about it; that courses on the former Yugoslavia and the Balkans are always full, and numerous publications have appeared, some of which is good, although most of them have sensational character. Thus, paradoxically, this tragedy helped the growing interest in this region. The only question is 
whether this trend is good and whether it leads to introducing region and creating a new discourse, because it is often structured by the same language stereotypes. The Balkans is, in fact, still a metaphor for many negatives. This does not mean that it cannot be changed, and that this term, which exceeds its primary geographical feature, is always used in such a manner. It is good that the experts from this region are engaged, but we should be careful that this story is not discursive hermetically, following the patterns by which some of the media reported from here; and thus remain the subject of a university course, because the reality says that, unfortunately, the media have a greater impact on a global picture than the relevant academic circles.

\section{REFERENCES $^{5}$}

Allan, S. (1997). News and the public sphere: towards a history of news objectivity. In M. Bromley \& T. O’Malley (Eds.), A Journalism Reader (pp. 296-330). London: Routledge.

Bakić-Hayden, M. (2006). Varijacije na temu 'Balkan'. Beograd: Filip Višnjić.

Barović, V. (2008). Teorijske pretpostavke za izveštavanje elektronskih medija iz regiona zahvaćenih ratnim dejstvima. CM Komunikacija i mediji, 3(9), 143-155.

Brock, P. (2006). Media cleansing: dirty reporting journalism \& tragedy in Yugoslavia (2nd ed.). Los Angeles: GM Books.

Djilas, A. (2003, June 23). Personal interview. Politika, p. 5.

Enzensberger, H. M. (1994). Civil wars: from LA to Bosnia. New York: New York Press.

Glenny, M. (2012). The Balkans: nationalism, war \& the great powers / 1804-1999 (updated ed.). New York: Penguin Books.

Goldsvorti, V. (2000). Izmišljanje Ruritanije: imperijalizam mašte. Beograd: Geopoetika.

Grant, T., \& Woods, A. (2006, January 24). Mesec dana bombardovanja: marksistička analiza Balkanske krize. In Defence of Marxism. Retrieved from http://www. marxist.com/marksisticka-analiza-balkanske-krize.htm. Revisited May 12, 2010.

Habermas, J. (1991). The structural transformation of the public sphere. Cambridge: MIT Press.

Hammond, P. (2000). Degraded capability: the media and the Kosovo crisis. London: Pluto Press.

5 Media reports in which the source was not named are a part of archives incurred in 2008 and 2009, during research in the United States, for the purpose of writing a paper about the attitude of the Western media against Serbia. During that period of time, Slobodan Penezić had a free access to the database such as www.factiva.com and www.lexisnexis.com. 
Herman, D. (2005, December 29). Media cleansing: dirty reporting journalism \& tragedy in Yugoslavia, by Peter Brock. Global Research. Retrieved January 12, 2020, from http://www.globalresearch.ca/index.php? context=va\&aid=1667.

Judah, T. (2009). The Serbs: history, myth and the destruction of Yugoslavia. New Haven: Yale University Press.

Jatras, S. L. (2001, January 15). The Media's War against the Serbs. Antiwar.com. Retrieved February 7, 2020, from http://antiwar.com/orig/jatras.php?articleid=1496.

Jevtović, Z. (2017). Medijski rat protiv Srba i Jugoslavije. In D. Kojčić \& J. Trivan (Eds.), Srbi i propast Jugoslavije (pp. 63-92). Beograd: Zavod za udžbenike; Službeni glasnik.

Jevtović, Z., \& Bajić, P. (2019). Propagandna kampanja u doktrini hibridnog ratovanja tokom NATO agresije. In Ž. Đurić \& M. Jevtić (Eds.), Dvadeset godina od NATO agresije na SRJ: povodi i posledice (pp. 107-128). Beograd: Institut za političke studije.

Johnston, D. (2000). Deception and self-deception: the mixed motives behind NATO's war against Yugoslavia. New York: Monthly Review Press.

Johnston, D. (2002). Fools' crusade: Yugoslavia, NATO, and Western delusions. New York: Monthly Review Press.

Jusić, T. (2008). Medijski diskurs i politika etničkog sukoba: jugoslovenski slučaj. In G. Đerić (Ed), Intima javnosti (pp. 40-63). Beograd: Fabrika knjiga.

Kaplan, R. D. (1993). Balkan ghosts. New York: St. Martin's Press.

Klun, B. (2000). Rat i mediji: etički izazov na kraju stoljeća. Medijska istraživanja: znanstveno-stručni časopis za novinarstvo i medije, 6(1), 75-87.

Kokanus. (1999, May). Režis Debre: žrtva intelektualnog profita [Blog post]. Retrieved December 12, 2019, from http://kokanus.blogspot.com/2010/04/rezis-debre-zrtva-intelektualnog.html.

Larson, E. V., \& Savych, B. (2006). Misfortunes of war: press and public reactions to civilian deaths in wartime. Santa Monica, CA: RAND Corporation. Retrieved December 2, 2019, from https://www.rand.org/pubs/monographs/MG441.html.

Mandel, M. (2004). How America gets away with murder: illegal wars, collateral damage and crimes against humanity. London: Pluto Press.

Marković, P. J. (2001). Transfer etničkih stereotipa: Balkan je negde drugde. Zagreb: Fridrich Naumann.

Model, D. (2005). The Applicability of Herman's and Chomsky's Propaganda Model Today. College Quarterly, 8(3). Retrieved from http://collegequarterly.ca/2005vol08-num03-summer/model.html. Revisited May 11, 2019.

Virilio, P. (2003). Personal interview. Nova srpska politička misao. Retrieved April 11, 2014, from http://starisajt.nspm.rs/Debate/debtem3polvirilio1.htm. 
Parenti, M. (2003, December). The demonization of Slobodan Milosevic [Blog post]. Retrieved February 2, 2019, from http://www.michaelparenti.org/Milosevic.html.

Predstavljanje knjiga Majkla Volzera. (2010, June 17). Retrieved February 10, 2013, from http://www.slglasnik.com/aktuelno/vesti/predstavljanje-knjiga-majkla-volzera.

Reljić, S. (2011). Odumiranje slobodnih medija. Beograda: Službeni glasnik.

Rorty, R. (1999). Achieving our country (new ed.). Cambridge: Harvard University Press.

Salmon, K. (2010). Storytelling. Beograd: Clio.

Šabec, K. (2004). Na dnu Evrope ili na vrhu Balkana. Sarajevske sveske, 6/7, 103-120. Retrieved June 3, 2010, from http://www.sveske.ba/bs/content/na-dnu-evrope-ilina-vrhu-balkana.

Simić, P. (2000, May 25). Žrtve istorijskih priručnika: Put u Rambuje. Nedeljnik NIN, (2578). Retrieved June 12, 2009, from http://www.nin.co.rs/2000-05/25/12802.html.

Šajkaš, M. (2007). Tranziciona pravda i uloga medija na Balkanu. International Center for Transitional Justice (ICTJ). Retrieved February 2, 2020, from http:// www.hlc-rdc.org/images/stories/Outreach/Regionalne_konsultacije/pristina/ Tranziciona_pravda_i_uloga_medija.pdf.

Todorova, M. (2006). Imaginarni Balkan. Beograd: Biblioteka XX vek.

Stojanovic, S. (1999, December 6). Spinning Kosovo: Media and Propaganda in a Post Modern War. The Center for Peace in the Balkans. Retrieved June 6, 2019, from http://balkanpeace.org/library/spinn1.html.

Vasović, M. (2004). Propagandne (ubeđivačke) tehnike u službi manipulacije javnim mnjenjem. In Z. Vacić (Ed.), Etika javne reči u medijima i politici (pp. 249-271). Beograd: Centar za liberalno-demokratske studije.

Vesković, M. (2008, November 4). Mediji i balkanski ratovi devedesetih. Nova srpska politička misao. Retrieved June 2, 2014, from http://www.nspm.rs/prikazi/mediji-i-balkanski-ratovi-devedesetih.html?alphabet=l.

Žaket, D. (2007). Novinarska etika. Beograd: Službeni glasnik. 
